\title{
STUDIES ON PYROLYSIS OF SPENT ENGINE OIL IN A QUARTZ
} LOAD CELL

\author{
Aparna Sarkar ${ }^{1}$, Michael Langanki ${ }^{2}$, Ranjana Chowdhury ${ }^{3}$ \\ ${ }^{1}$ PhD Scholar, Chemical Engineering Department, Jadavpur University, West Bengal, India \\ ${ }^{2}$ Student, Chemical Engineering Department, Engler Bunte Institute (Gas Erdol Kohle), Karlsruhe, Germany \\ ${ }^{3}$ Professor, Chemical Engineering Department, Jadavpur University, West Bengal, India
}

\begin{abstract}
Every year gallons of waste automobile lubricating oil are generated in India. With the rapid growth of automobile industries, volume of waste lubricating oil is increasing at a high rate. The regeneration of these waste oils depends on its PCBs and PCTs value. If the value is lower than 50 ppm then legally the waste oil can be used otherwise it must be incinerated. In very recent years, pyrolysis method has been practiced to remove the pollutants from waste oil. Pyrolysis method has also been applied due to the production of either char or oil or gases at a time and these pyrolysis products may be maximized by the adjustment of process conditions. Under the present investigation, spent engine oil is pyrolysed in a $30 \mathrm{~mm}$ diameter and $195 \mathrm{~mm}$ long quartz load cell placed in a tubular furnace from $573 \mathrm{~K}$ to $873 \mathrm{~K}$ in a nitrogen atmosphere. The calorific value of this oil sample is $46 \mathrm{MJ} / \mathrm{kg}$, determined in a bomb calorimeter. The spent engine oil sample is also pyrolysed in a Thermogravimetric analyzer (TGA) under the same experimental conditions. The TGA analysis has been performed at constant heating rate, $10{ }^{\circ} \mathrm{C} / \mathrm{min}$. A kinetic scheme has been proposed where two parallel reactions occur simultaneously to produce volatiles and char. The kinetic rate constants of both the reactions have been determined in the temperature range under study. Reaction kinetics of formation of pyro-oil and gaseous product from feed material has also been determined in present range of reaction temperature. The activation energies and pre-exponential factors of all products (volatile, char, pyro-oil and gas) have been determined. The calorific values of pyrooil obtained from pyrolysis of spent engine oil at temperature of $673 \mathrm{~K}, 773 \mathrm{~K}$ and $873 \mathrm{~K}$ have been determined to be values 56 $\mathrm{MJ} / \mathrm{kg}, 62 \mathrm{MKJ} / \mathrm{kg}$ and $58 \mathrm{MJ} / \mathrm{kg}$ respectively.
\end{abstract}

Keywords: Pyrolysis, Spent engine oil, Load cell, and pyro-products

\section{INTRODUCTION}

Waste treatment is becoming one of the major issues in metropolitan cities like Kolkata. Few wastes, generated abundantly, are difficult to recycle or landfilled or incinerate without energy recovery. Spent engine oil (SEO) is one of them. Spent engine oil is to be considered as environmental hazardous waste and could not be treated or disposed due to the presence of polycyclic aromatic hydrocarbons (PAHs) and few additives and impurities. There are several processes through which waste oil may be re-refined [1-3]. The Philips re-refining process combines chemical dematerialization with hydro treatment to produce yields of base oil from waste lubes [1]. There are other processes in which waste lubricating oil is mixed with atmospheric distillation residuum from crude oil and moisture is subsequently distilled under vacuum to obtain different products. However, these methods of regeneration of waste lubricating oil are no longer practicable because of involvement of disposal of sludge. A better solution from the environmental point of view is thus required. The conversion of waste to energy is always welcome. The recovery of energy from the waste materials may be done through thermochemical processes like combustion, gasification and pyrolysis. Among all these routes, pyrolysis method has been receiving increasing attention in recent years as an acceptable route for waste to energy conversion. Pyrolysis is a thermochemical process in which hydrocarbon rich solid or liquid feed materials are thermally degraded to char, condensable tar and non-condensable gaseous component in an inert atmosphere. The usual range of pyrolysis temperature is $573 \mathrm{~K}$ to $1173 \mathrm{~K}$. The unique feature of this method is that the production of pyro-products may be maximized just by the adjustment of process conditions. From an extensive literature survey, it is apparent that the chemical kinetics of spent engine oil has not yet been studied thoroughly. Few literatures have been reported on the pyrolysis of car engine oil [4], Moroccan (Tarfaya) oil shale [5], waste automobile lubricating oil [6, 7], oil sludge [8], synthetic engine oil [9], heavy pyrolytic oil [10], industrial waste oil [11], automotive engine oil [12, 13], lube oil [14] and machinery oil [15]. However, no attempt has so far been made to develop kinetic models for the pyrolysis of spent engine oil of Indian origin.

Under the present investigation, spent engine oil is pyrolysed in a quartz load cell placed in a tubular furnace from $573 \mathrm{~K}$ to $873 \mathrm{~K}$ in nitrogen atmosphere. The spent engine oil sample is also pyrolysed in a thermogravimetric analyser (TGA) under the same experimental conditions. The calorific values of raw material and pyo-oil have been determined using a bomb calorimeter. The activation energies and pre exponential factors have been determined for pyro-oil and gaseous product formation. 


\section{MATERIALS AND METHODS}

\subsection{Materials}

The spent engine oil (SEO) was collected from Maruti Service Station near Jadavpur Police station, Kolkata, India. The proximate and ultimate analyses of feed stock have been mentioned in Table 1.

Table-1: Proximate and ultimate analyses of SEO

\begin{tabular}{|l|l|l|l|}
\hline \multicolumn{2}{|l|}{$\begin{array}{l}\text { Proximate analysis } \\
(\% \text { w/w })\end{array}$} & \multicolumn{2}{l|}{$\begin{array}{l}\text { Ultimate analysis } \\
(\% \text { w/w })\end{array}$} \\
\hline Moisture & 1 & Carbon & 84.95 \\
\hline $\begin{array}{l}\text { Volatile } \\
\text { matter }\end{array}$ & 98.5 & Hydrogen & 11.70 \\
\hline Ash content & 0.5 & Nitrogen & Nil \\
\hline Fixed carbon & nil & & \\
\hline
\end{tabular}

\subsection{Experimental}

\subsubsection{Pyrolysis Set-Up}

A $30 \mathrm{~mm}$ diameter and $195 \mathrm{~mm}$ long cylindrical quartz cell was hung by a stainless steel wire and was inserted into the furnace. The experimental set-up is shown in fig. 1. Experiments were conducted for 10, 20, 30, 40, 50, 60 minutes. The outlet vapour from the quartz reactor was condensed using two condensers and non-condensable gas was finally passed through a silica gel bed and collected for analysis. Pyro-oil and char product char were collected from the condenser and the quartz pyrolyser respectively. From the experimental data on yield of char, pyro-oil and gas yield, the kinetics of pyrolysis of spent engine oil with respect to the formation of char, oil and gas have been determined.

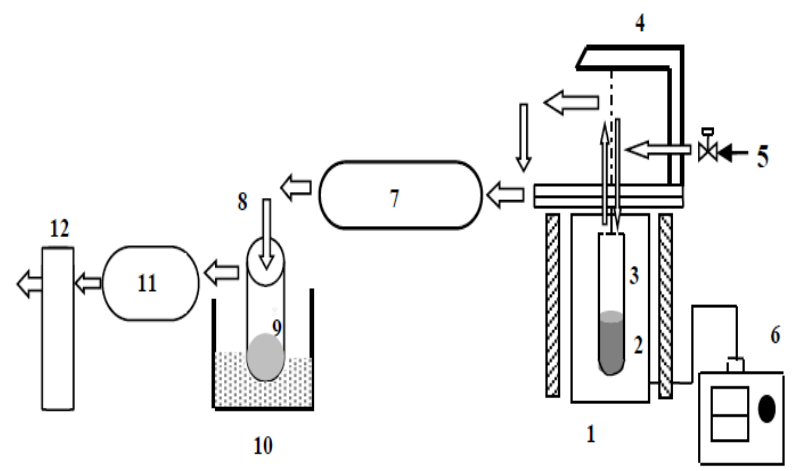

Fig- 1:.1. Tubular furnace, 2. Spent engine oil, 3. Quartz load cell, 4. A steel stand, 5. $\mathrm{N}_{2}$ gas supply, 6. PID controller, 7. Condenser (1), 8. Condenser (2), 9. Pyro-oil, 10. Ice bath, 11. Silica gel bed, 12. Gas sampling

\subsubsection{TGA Analysis}

TGA analysis of spent engine oil was conducted in the temperature range of 26 to $700{ }^{\circ} \mathrm{C}$. The heating rate was $10^{\circ} \mathrm{C} / \mathrm{min}$. The model of the TGA machine is Pyris Diamond TG/DTA. The flow rate of $\mathrm{N}_{2}$ gas was $150 \mathrm{ml} / \mathrm{min}$. In Figure 2 percentage of weight residue has been plotted against corresponding temperature. From close observation of the data, it appears that the pyrolysis reactions proceeds considerably in the temperature range of 26 to $700{ }^{\circ} \mathrm{C}$.

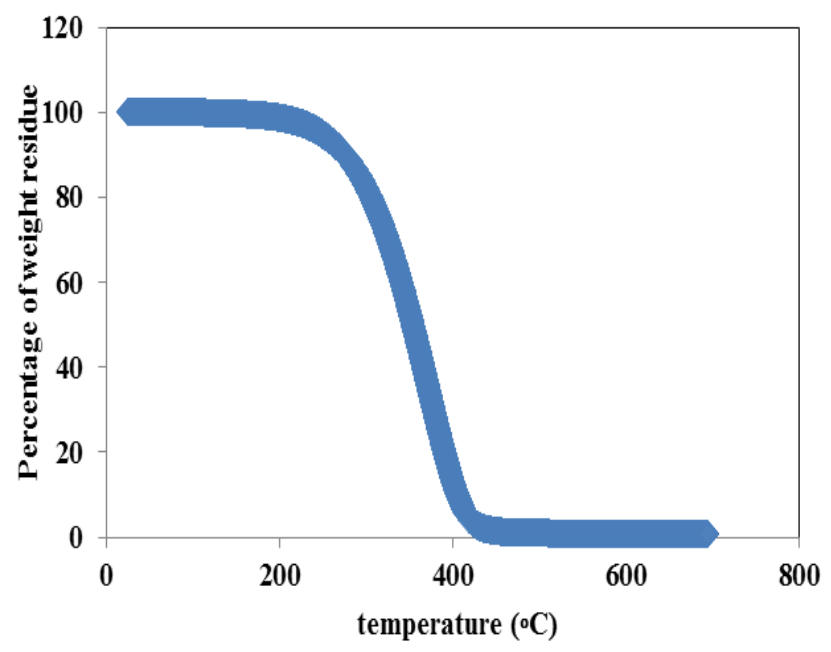

Fig- 2:.Percentage of weight residue of spent engine oil in the temperature range of 26 to $700{ }^{\circ} \mathrm{C}$ (TGA plot)

\section{PYROLYSIS KINETICS}

The pyrolysis of spent engine oil proceeds through complex reactions in series, parallel or combination of both. The reaction pathway is as follows,

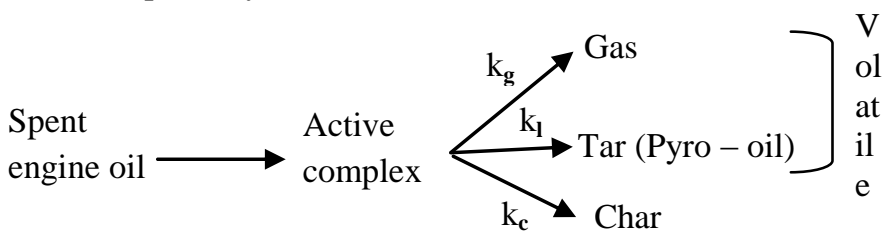

Rate constants $\mathrm{k}, \mathrm{k}_{\mathrm{v}}, \mathrm{k}_{\mathrm{l}}, \mathrm{k}_{\mathrm{g}}$ and $\mathrm{k}_{\mathrm{c}}$ at different pyrolysis temperatures have been evaluated using the present experimental data. The reaction kinetics of volatile and char has been elaborately discussed in pyrolysis of coconut shell [16], vegetable market wastes [17] and textile wastes [18].

\subsection{Reaction Kinetics of Liquid (pyro-oil) and Gas}

The weight loss profile of the pyro oil $W_{l}$ and the gas $W_{g}$ with time may be given by,

$$
\begin{aligned}
& \frac{d W_{l}}{d t}=k_{l} W \\
& \frac{d W_{g}}{d t}=k_{g} W
\end{aligned}
$$

The profile of increase of weights of pyro-oil and gas against time are given respectively by the following expressions,

$$
\frac{d W_{l}}{d t}=k_{l} W=k_{l} W_{0} \exp (-k t)
$$




$$
\frac{d W_{g}}{d t}=k_{g} W=k_{g} W_{0} \exp (-k t)
$$

Equations (3) and (4) have been solved analytically,

$$
W_{g}=W_{v}-W_{l}
$$

Regression analysis of equations (3) and (4) gives the values of the rate constants $k_{l}, k_{g}$ respectively, at different temperatures. The activation energies and frequency factors of all reactions have been reported in table 2 .

Table-2: Calculated Activation Energies and Frequency Factors as per Arrhenius Law

\begin{tabular}{|l|l|l|}
\hline $\begin{array}{l}\text { Reaction rate } \\
\text { constant }\end{array}$ & $\begin{array}{l}\text { Frequency factor } \\
\left(\mathrm{min}^{-1}\right)\end{array}$ & $\begin{array}{l}\text { Activation energy } \\
(\mathrm{kJ} / \mathrm{mol})\end{array}$ \\
\hline $\mathrm{k}$ & $1.34 \times 10^{2}$ & 42.44 \\
\hline $\mathrm{k}_{\mathrm{v}}$ & $1.69 \times 10^{3}$ & 58.58 \\
\hline $\mathrm{k}_{\mathrm{c}}$ & $5.29 \times 10^{-10}$ & 97.37 \\
\hline $\mathrm{k}_{\mathrm{l}}$ & $7.91 \times 10^{8}$ & 123.57 \\
\hline $\mathrm{kg}$ & $7.84 \times 10^{4}$ & 67.50 \\
\hline
\end{tabular}

\section{RESULTS AND DISCUSSIONS}

\subsection{Weight Loss Profile of SEO}

Figure 3 shows the percentage of experimental weight fraction profile of residue with respect to time in isothermal conditions at $573 \mathrm{~K}, 673 \mathrm{~K}, 773 \mathrm{~K}$ and $873 \mathrm{~K}$. From close observation of the data, it appears that the pyrolysis reactions proceed considerably in the temperature range of $573 \mathrm{~K}$ to $873 \mathrm{~K}$.

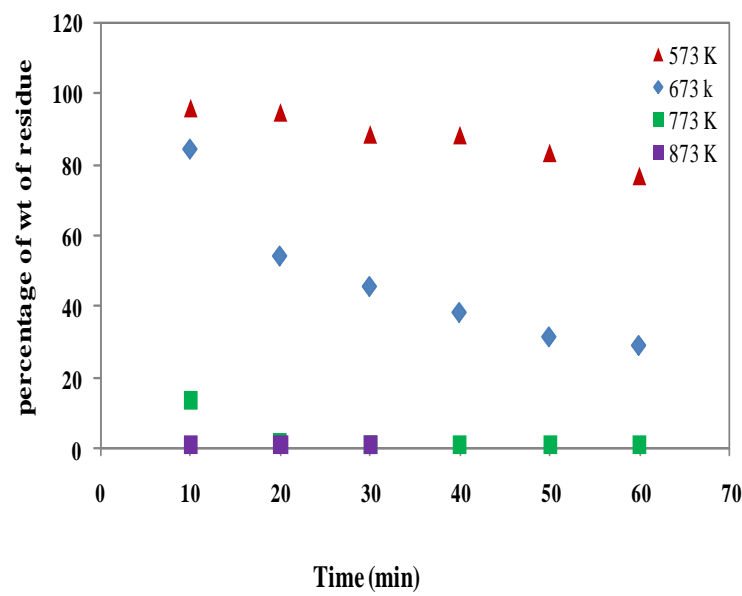

Fig- 3: Variation of percentage of weight of residue of SEO with respect to time at different temperature

\subsection{Pyrolysis Kinetics}

In Figure 4, the rate constants $k$ and $k_{v}$ calculated using Activation energies and frequency factors reported in table
2, have been plotted in the logarithmic scale against reciprocal of temperature.

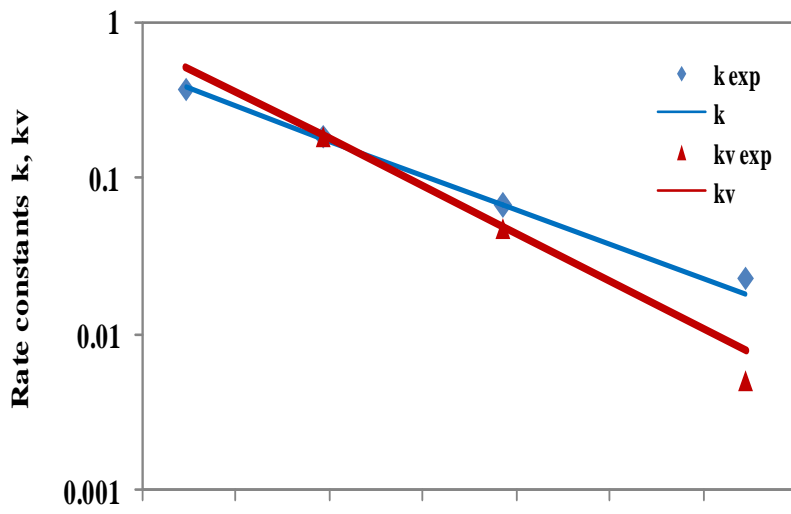

$\begin{array}{llllllll}0.0011 & 0.0012 & 0.0013 & 0.0014 & 0.0015 & 0.0016 & 0.0017 & 0.0018\end{array}$

1/Temperature (1/K)

Fig- 4: Simulated k, kv and experimental k, kv values of rate constant for weight loss of spent engine oil, Volatile formation in logarithmic scale against reciprocal of temperature

All the rate constants calculated from the experimental results in the temperature range of 573 to $773 \mathrm{~K}$ have also been superimposed on the same figure. From the figure, it is apparent that the agreement between actual values or model predicted values of rate constants and experimental values is satisfactory. Thus the applicability of mathematical model for the present system is validated.

\subsection{Effect of Pyrolysis Temperature on Pyro-Oil}

\section{Yield}

After completion of pyrolysis of spent engine oil (SEO) the condensable part of volatile content was considered as pyrooil. The gas yield was calculated by subtracting the amount of pyro-oil from volatile yield. The yields of pyro-oil in relation to reactor temperature $(673,773$ and $873 \mathrm{~K})$ are shown in fig. 5, 6 and 7 .

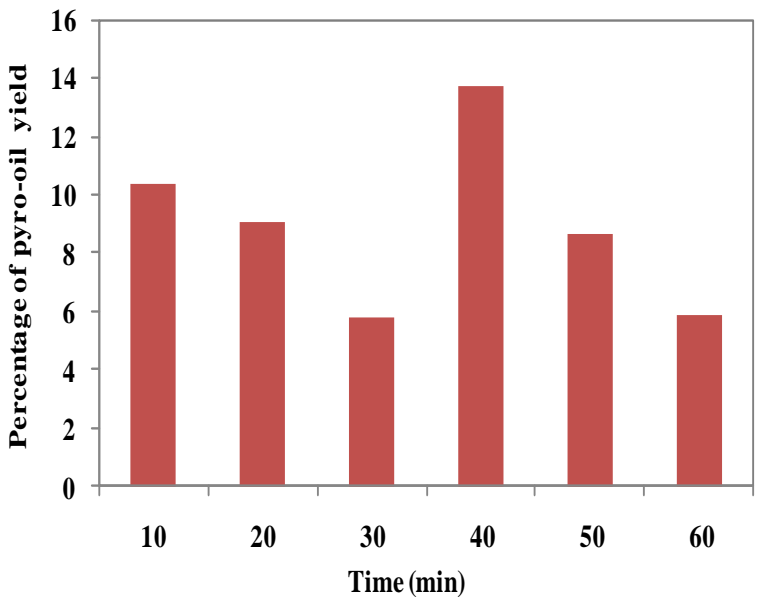


Fig-5: Effect of temperature (673K) on pyro-oil yield obtained from spent engine oil

From fig. 5 it is clear that the yields of pyro-oil increased from $10 \%$ to $14 \%$ from 10 to 40 mints at $673 \mathrm{~K}$. Beyond this time the yields of pyro-oil has decreased. The reason is that the pyro-oil participates in heterogeneous reactions with gaseous product.

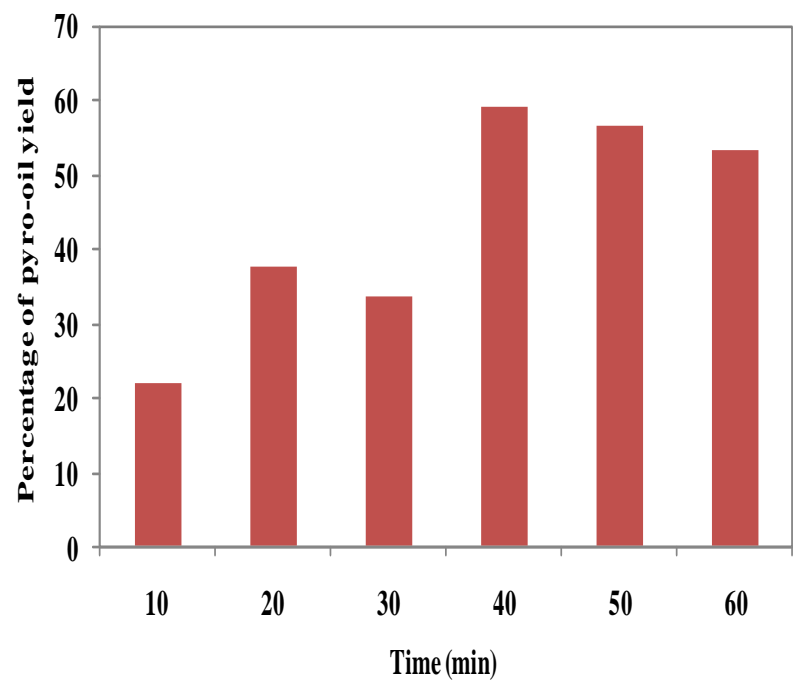

Fig-6: Effect of temperature (773K) on pyro-oil yield obtained from spent engine oil

The effect of pyrolysis temperature (773K) on pyro-oil yield is shown in Figure 6. It is clear from the figure that the pyrooil increased from $22 \%$ to $58 \%$ up to 40 mints. Similar trend of pyro-oil has been observed in case of $773 \mathrm{~K}$ temperature.

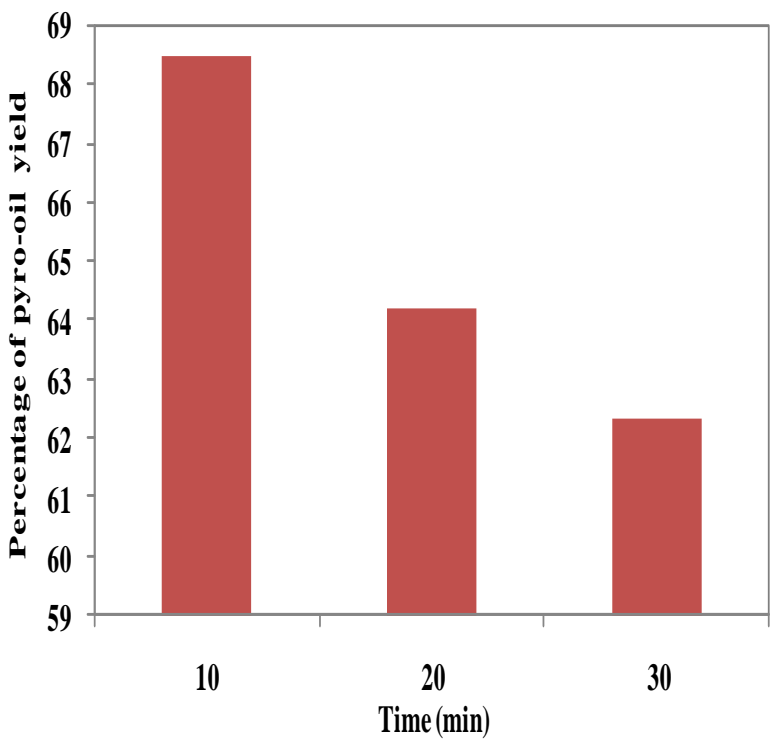

Fig-7: Effect of temperature (873K) on pyro-oil yield obtained from spent engine oil
The effect of $873 \mathrm{~K}$ temperature on pyro-oil yield is shown in fig. 7. At higher temperature the pyro-oil product has been decreased from $69 \%$ to $66 \%$ up to 30 minute.

\subsection{Effects of Pyrolysis Temperature on Calorific Value of Product Yields}

The calorific values of SEO and pyro-oil obtained at different pyrolysis temperatures have been determined using the bomb calorimeter. The calorific value of SEO is 46 $\mathrm{MJ} / \mathrm{kg}$. The gross calorific values of pyro-oil at different temperatures are mentioned in table 3.

Table-3: Calorific values of pyro-oil at different temperatures

\begin{tabular}{|l|l|l|}
\hline S1. No & Temperatures (K) & Pyro-oil (MJ/kg) \\
\hline 1. & 573 & 50 \\
\hline 2. & 673 & 56 \\
\hline 3. & 773 & 62 \\
\hline 4. & 873 & 58 \\
\hline
\end{tabular}

The calorific value of pyro-oil increased gradually from 50 to $62 \mathrm{MJ} / \mathrm{Kg}$ as temperature is increased from $573 \mathrm{~K}$ to $773 \mathrm{~K}$. Beyond $773 \mathrm{~K}$ the calorific value decreased from 62 to $58 \mathrm{MJ} / \mathrm{Kg}$ as the temperature is changed from $773 \mathrm{~K}$ to $873 \mathrm{~K}$. This may be justified by the fact that fraction of carbon in pyro-oil increases as the temperature increases up to $773 \mathrm{~K}$, beyond which pyro-oil further participates in heterogeneous reactions with gaseous product.

\section{CONCLUSIONS}

In the present investigation, pyrolysis of spent engine oil has been studied in the temperature range of $573 \mathrm{~K}$ to $873 \mathrm{~K}$. The calorific values of pyro-oil at different pyrolysis temperatures of $673 \mathrm{~K}$ to $873 \mathrm{~K}$ are 56,62 and 58 respectively, determined using bomb calorimeter. A kinetic model has been represented the reaction rate. The activation energies and frequency factors have been determined. This model has been found to be successful to explain the reaction engineering behaviour of the system.

\section{ACKNOWLEDGEMENTS}

The authors gratefully acknowledge Council of Scientific \& Industrial Research (CSIR), India for their financial support.

\section{NOMENCLATURE}

$k=$ rate constant, $\left(\mathrm{min}^{-1}\right)$

$k_{v}=$ rate constant for volatiles formation, $\left(\mathrm{min}^{-1}\right)$

$k_{c}=$ rate constant for char formation, $\left(\mathrm{min}^{-1}\right)$

$k_{l}=$ rate constant for liquid formation, $\left(\mathrm{min}^{-1}\right)$

$k_{g}=$ rate constant for gas formation, $\left(\mathrm{min}^{-1}\right)$

$t=$ time, (minute)

$W=$ weight fraction of the reactant to the basis of its initial weight

$W_{v}=$ weight fraction of the volatiles to the basis of its initial weight of the reactant

$W_{l}=$ weight fraction of the liquid (pyro-oil) 
$W_{g}=$ weight fraction of the gas

Subscripts

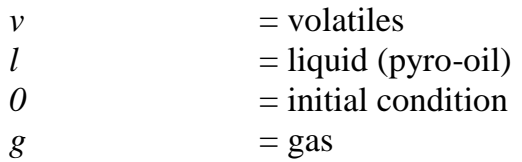

\section{REFERENCES}

[1] Linnard, R. E., Henton, L. M., Hydrocarbon processing, 58, 148, 1979.

[2] Sequeira, A., Sherman, P. B., Douciere, J.U., McBride EO. Hydrocarbon processing, 58, 155, 1979.

[3] Reynolds, J.W., Whismam, M.L., Thompson, C.J., Hydrocarbon processing, 56, 128, 1977.

[4] Lam, S. S., Russell, A. D., Chase, H. A., Pyrolysis Using Microwave Heating: A Sustainable Process for Recycling UsedCar Engine Oil, Ind. Eng. Chem. Res., 49, 10845-10851, 2010.

[5] Harfi, K. E., Mokhliss, A., Chana, M. B., Outzourhit, A., pyrolysis of the Moroccan (Tarfaya) oil shales under microwave irradiation, Fuel, 79, 733-742, 2000.

[6] Kim, S. S, Kim, S. H., Pyrolysis kinetics of waste automobile lubricating oil, Fuel, 79, 1943-1949, 2000.

[7] Shie, J. L., Lin, J. P., Chang, C. Y., Lee, D. J., Wu, C. H., Pyrolysis of oil sludge with additives of sodium and potassium compounds, Resources, Conservation and Recycling, 51, 39, 2003.

[8] Owrang, F., Mattsson, H., Olsson, J., Pedersen, J., Investigation of oxidation of a mineral and a synthetic engine oil, Thermochimica Acta, 241, 413, 2004.

[9] Fuentes, M. J., Font, R., Gomez-Rico, M. F., MartinGullon, I., Pyrolysis and combustion of waste lubricant oil from diesel cars: Decomposition and pollutants, J. Anal. Appl. Pyrolysis, 79, 215-226, 2007.

[10] Lee, K.-H., Thermal degradation of heavy pyrolytic oil in a batch and continuous reaction system, $\mathrm{J}$. Anal. Appl. Pyrolysis, 86, 348-353, 2009.

[11] Nerın, C., Domeno, C, Moliner, R., Lazaro, M .J., Suelves, I., Valderrama, J., Behaviour of different industrial waste oils in a pyrolysis process: metals distribution and valuable products, Journal of Analytical and Applied Pyrolysis, 55, 171-183, 2000.

[12] Lam, S. S., Russell, A. D., Chase, H. A., Microwave pyrolysis, a novel process for recycling waste automotive engine oil, Energy, 35, 2985-2991, 2010.

[13] Lam, S. S., Russell, A. D., Lee, C. L., Chase, H. A., Microwave-heated pyrolysis of waste automotive engine oil: Influence of operation parameters on the yield, composition, and fuel properties of pyrolysis oil, Fuel, 92, 327-339, 2012.

[14] Gomez-Rico, M. F., Martin-Gullon, I., Fullana, A., Conesa, J. A., Font, R., Pyrolysis and combustion kinetics and emissions of waste lube oils, J. Anal. Appl. Pyrolysis, 68, 527-546, 2003.
[15] Sinag, A., Gulbay, S., Uskan, B., Ucar, S., Ozgurler, S. B., Production and characterization of pyrolytic oils by pyrolysis of waste machinery oil, Journal of Hazardous Materials, 173, 420-426, 2010.

[16] Bandhyopadhyay, S., Chowdhury, R., Biswas, G. K., Thermal deactivation studies of coconut shell pyrolysis, The Can. J. Chem. Eng., 77, 1028-1036, 1999.

[17] Roy, R., Bhattachariya, P., Chowdhury, R., Simulation and modeling of vegetable market wastes pyrolysis under progressive deactivation conditions, The Can. J. Chem. Eng., 82, 566-579, 2004.

[18] Chowdhury, R., and Sarkar, A., Reaction Kinetics and Product Distribution of Slow Pyrolysis of Indian Textile Wastes, International Journal of Chemical Reactor Engineering, 10 article A67, 2012.

\section{BIOGRAPHIES}

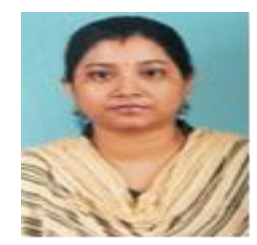

Aparna Sarkar is working under Prof. Ranjana Chowdhury as senior research fellow in the chemical engineering department of Jadavpur University. Presently her research interest is on pyrolysis of different municipal solid wastes (MSW) and spent engine oil and mathematical modeling of pyrolyzer.

Michael Langanki is a B. E Student of Chemical Engineering Department of Engler Bunte Institute (Gas Erdol Kohle), Karlsruhe, Germany. He did a six months internship under the supervision of Prof. Ranjana Chowdhury in Jadavpur University.

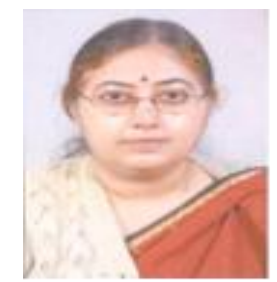

Ranjana Chowdhury is working as a Professor in the Chemical Engineering department of Jadavpur university. Presently her research interest is on novel and advanced chemical reaction engineering, bioprocess engineering, non-conventional energy and mathematical modeling of chemical and bio- reactors. 